STUDIA PRAWNO-EKONOMICZNE, T. CIX, 2018

PL ISSN 0081-6841; e-ISSN 2450-8179 $\quad$ s. 303-326

https://doi.org/10.26485/SPE/2018/109/19

\title{
Katarzyna SKORUPIŃSKA-CIEŚLAK*
}

\section{STOSUNKI PRZEMYSŁOWE W KRAJACH EUROPY ŚRODKOWO-WSCHODNIEJ. PERSPEKTYWA PORÓWNAWCZA}

\section{(Streszczenie)}

Celem artykułu jest porównanie elementów składowych stosunków przemysłowych w krajach Europy Środkowo-Wschodniej (EŚW) i określenie poziomu ich konwergencji w stosunku do średniej unijnej. Analizy dokonano na podstawie danych statystycznych z bazy Eurostatu, OECD, ILO, AMECO i ICTWSS. Do oceny siły ,pracowniczego głosu” w tych krajach wykorzystano Indeks Partycypacji Pracowniczej (IPP) obejmujący partycypację związkową, reprezentację pracowniczą w postaci rad zakładowych oraz reprezentację w organach nadzoru. Wyniki analiz wskazują, że pomimo upodabniania się stosunków przemysłowych w grupie krajów EŚW zróżnicowanie między poszczególnymi krajami jest nadal znaczne. Okazało się, że najwyższe wartości IPP posiadają Słowenia i Chorwacja, z kolei w Bułgarii siła „,pracowniczego głosu” jest najniższa.

Słowa kluczowe: indeks partycypacji pracowniczej; konwergencja; stosunki pracy

Klasyfikacja JEL: J31, J50, J53, J83, F66

\section{Wstęp}

Stosunki przemysłowe ${ }^{1}$ tworzą wzajemnie od siebie uzależnione elementy, tj. aktorzy stosunków przemysłowych (związki zawodowe i inne przedstawicielstwa pracowników, organizacje pracodawców i państwo) oraz procesy (układy zbiorowe i konflikty przemysłowe) ${ }^{2}$. Przed wejściem do UE stosunki przemysłowe w krajach Europy Środkowo-Wschodniej charakteryzowały się szybkim spadkiem poziomu „uzwiązkowienia”, słabością organizacji pracodawców, istotnie

* Dr, Uniwersytet Łódzki, Wydział Ekonomiczno-Socjologiczny; e-mail: katarzyna.skorupinska@uni.lodz.pl

1 Stosunki przemysłowe są często utożsamiane ze stosunkami pracy.

2 J.T. Dunlop, Industrial Relations System, H. Holt and Company, New York 1958, s. 7. 
niższym w porównaniu z krajami UE-15 zasięgiem układów zbiorowych, słabo wykształconym systemem sektorowych porozumień zbiorowych oraz słabością instytucji partycypacji pracowniczej. Akcesji tych krajów do Unii towarzyszyły nadzieje nie tylko na dynamiczny wzrost gospodarczy, ale również na poprawę standardów pracy i rozwój instytucji partycypacji pracowniczej. Nadzieje te zostały częściowo spełnione przez obserwowany aż do 2007 r. proces konwergencji tych krajów ${ }^{3}$. W obszarze stosunków przemysłowych największy stopień konwergencji był zauważalny w odniesieniu do partycypacji pracowniczej w przedsiębiorstwach ze względu na efekt implementacji dyrektyw unijnych. Z kolei w tych elementach stosunków przemysłowych kształtowanych przez narodową tradycję i regulacje poszczególnych krajów te różnicie między „starymi” i „nowymi” krajami były największe ${ }^{4}$. Należy pamiętać także o kwestii podkreślanej przez M. Lissowską, iż zmiany w obszarze stosunków przemysłowych odbywały się równolegle ze zmianami instytucji i struktur na rynku pracy5.

Celem artykułu jest porównanie głównych elementów składowych stosunków przemysłowych w 11 krajach Europy Środkowo-Wschodniej (EŚW $)^{6}$ oraz określenie kierunków i siły zmian tych wielkości. W artykule dokonano również oceny siły „pracowniczego głosu” w krajach EŚW za pomocą skonstruowanego do tych potrzeb indeksu partycypacji pracowniczej oraz przeprowadzono próbę analizy poziomu konwergencji wybranych wskaźników makroekonomicznych. Dane statystyczne do przeprowadzanych $w$ artykule analiz pochodzą z bazy statystycznej Eurostatu, OECD, ILO, AMECO, ICTWSS. Struktura opracowania jest następująca: w sekcji 2 przedstawiono dokonujące się od okresu transformacji gospodarczej zmiany w klasyfikacji stosunków przemysłowych w Europie. Sekcja 4 to analiza makroekonomicznego otoczenia stosunków przemysłowych, zaś sekcja 5 przedstawia zmiany w poziomie „uzwiązkowienia”, zasięgu umów zbiorowych i poziomie partycypacji pracowniczej w krajach EŚW i ich stopnia konwergencji do średniej unijnej. Ostatnim elementem opracowania jest podsumowanie przeprowadzonych analiz.

3 B. Greskovits, Ten years of enlargement and the forces of labour in Central and Eastern Europe, Transfer 2015/21 (3), s. 271; H. Kohl, Convergence and divergence - 10 years since EU enlargement, Transfer 2015/21 (3), s. 285.

4 Zob. K. Skorupińska, Convergence and Disparities in European Industrial Relations, Comparative Economic Research 2013/16 (3), s. 127-146.

5 M. Lissowska, The financial crisis and changing labour markets in post-transition countries, European Journal of Industrial Relations 2017/23 (1), s. 17-32.

6 W niniejszym artykule do grupy krajów Europy Środkowo-Wschodniej zaliczam 11 krajów UE: Estonię, Litwę, Łotwę, Polskę, Czechy, Słowację, Słowenię i Węgry, które stały się członkami UE 1 maja 2004 r., Bułgarię i Rumunię - przyjęte do UE 1 stycznia 2007 r. oraz Chorwację, pomimo stosunkowo krótkiego okresu członkostwa w UE (od 1 lipca 2013 r.). 


\section{Modele stosunków przemysłowych}

W okresie transformacji gospodarczej kraje Europy Środkowo-Wschodniej cechowały się iluzorycznym korporatyzmem. Ten termin wprowadzony przez D. Osta oznaczał czysto symboliczne ustępstwa oferowane związkom zawodowym przez rządzących, które wykorzystywały związki w celu pieczętowania i legitymizacji neoliberalnych reform przez nie przeprowadzanych ${ }^{7}$. H. Kohn i H.W. Platzer ${ }^{8}$ wskazywali, że kraje te tworzą tzw. ,przejściowy” model stosunków przemysłowych, który charakteryzował się słabością instytucjonalną reprezentacji interesów pracowniczych i dominującą rolą państwa $\mathrm{w}$ formułowaniu celów polityki społeczno-ekonomicznej. Model ten był generalnie postrzegany jako wspólny dla krajów EŚW i po rozszerzeniu UE w 2004 r. dopełnił zestaw czterech modeli funkcjonujących w starych 15 krajach UE, tzn. modelu anglosaskiego, kontynentalnego, południowoeuropejskiego i nordyckiego. Kraje EŚW określano również jako tzw. ,zależne gospodarki rynkowe" (dependent market economies) ze względu na decydujący wpływ kapitału zagranicznego na restrukturyzację gospodarek, bezpośrednie inwestycje zagraniczne jako najważniejsze źródło kapitału i technologii oraz ogromne zaangażowanie przedsiębiorstw transnarodowych w funkcjonowanie rynków w tym regionie ${ }^{9}$.

Pewnego uszeregowania tych krajów pod względem typologii stosunków przemysłowych dokonał J. Sroka, wskazując na rozwinięcie się hybrydowych form, w zakresie których splatają się ze sobą elementy pluralizmu, korporatyzmu i etatyzmu. Według tego uszeregowania Estonię, Słowenię i częściowo Łotwę oraz Węgry można było zaliczyć do grupy krajów z najbardziej wolnorynkowymi stosunkami przemysłowymi. Z kolei Polska była krajem z kombinacją etatyzmu i słabego korporatyzmu ${ }^{10}$. Wyraźnego wyróżnienia $\mathrm{w}$ ramach grupy krajów EŚW trzech typów stosunków przemysłowych, tj. neoliberalizmu, „zakorzenionego" (embedded) neoliberalizmu i neokorporatyzmu dokonali

7 D. Ost, Illusory corporatism in Eastern Europe: Neoliberal tripartism and postcommunist class identities, Policies \& Society 2000/28 (4), s. 503-530.

8 H. Kohl, H.W. Platzer, Industrial Relations in Central and Eastern Europe: A Comparison of Eight New EU Member States, ETUI, Brussels 2004.

9 A. Nölke, A. Vliegenthart, Enlarging the varieties of capitalism: The emergence of dependent market economies in East Central Europe, World Politics 2009/61 (4), s. 670-702.

10 J. Sroka, Dialog społeczny i stosunki przemysłowe w krajach Europy Środkowo-Wschodniej, w: A. Antoszewski (red.), Systemy polityczne Europy Środkowo-Wschodniej. Perspektywa porównawcza, Wydawnictwo Uniwersytetu Wrocławskiego, Wrocław 2006, s. 167-192. 
w 2012 r. D. Bohle i B. Greskovits ${ }^{11}$. W swojej klasyfikacji podkreślają oni dwa główne elementy, tj. polityczne wybory państw w zakresie welfare i instytucji stosunków przemysłowych oraz międzynarodowe wpływy zarówno rynków innych krajów, UE, jak i przedsiębiorstw transportowych. Estonia, Łotwa, Litwa, Bułgaria i Rumunia zostały włączone do neoliberalnego modelu charakteryzującego się ograniczoną rolą państwa, fragmentarycznymi formami welfere state i silną zależnością od bezpośrednich inwestycji zagranicznych i przedsiębiorstw transnarodowych $\mathrm{w}$ sektorach produkcji i usług o niskim poziomie techniki. Z kolei Polskę, Czechy, Węgry i Słowację zdefiniowano jako kraje „zakorzenionego" neoliberalizmu ze znaczącą pozycją zagranicznych inwestycji bezpośrednich i przedsiębiorstw transnarodowych, połączeniem elastycznego rynku pracy z bardziej szczodrymi formami welfere state i słabością instytucji dialogu społecznego. Jedynie Słowenia została określona jako kraj neokorporatystyczny $\mathrm{z}$ hojnymi formami welfare state, ograniczoną zależnością od bezpośrednich inwestycji zagranicznych, bardzo wysokimi wskaźnikami uzwiązkowienia i zasięgu umów zbiorowych ${ }^{12}$.

Najnowszej klasyfikacji stosunków przemysłowych dokonał w 2018 r. R. Hyman w artykule What future for industrial relations in Europe? ${ }^{13}$ Identyfikuje on cztery główne wzorce (kategorie), zaznaczając, że granice między nimi są nieprecyzyjne. Pierwszy wzorzec dotyczy krajów, które podlegają silnym zewnętrznym restrykcjom i wymogom służącym osłabieniu ustawodawstwa dotyczącego ochrony zatrudnienia, decentralizacji umów zbiorowych i osłabieniu lub zniesieniu rozszerzania tych umów. R. Hyman zalicza do tego pierwszego modelu następujące kraje: Hiszpanię, Grecję, Portugalię, Irlandię, Rumunię i Słowenię. Z kolei kategoria druga obejmuje Wielką Brytanię, Francję i Włochy, w których mniejsza (niż w przypadku wzorca pierwszego) zewnętrzna presja wzmocniła występujące wcześniej silne wewnętrzne ruchy w kierunku liberalizacji. Kategoria trzecia dotyczy większości krajów EŚW, nie w pełni jeszcze zintegrowanych z globalnym finansowym rynkiem i w związku z tym mniej narażonych i mniej dotkniętych przez kryzys gospodarczy (poza krajami bałtyckimi). Ostatnia czwarta kategoria to kraje nordyc-

11 D. Bohle, B. Greskovits, Capitalist on Europe's Periphery, Cornell University Press, New York 2012.

12 V. Glassner, Central and Eastern European industrial relations in the crisis: National divergence and path-dependent change, Transfer 2013/19 (2), s. 155-169; Industrial Relations in Europe 2012, EC, Luxembourg 2013.

13 R. Hyman, What future for industrial relations in Europe?, Employee Relations 2018/40 (2), s. 569-579. 
kie i stare kraje Europy centralnej, w których presja na transformację stosunków przemysłowych w okresie kryzysu była stosunkowo niewielka i miała charakter głównie wewnętrzny ${ }^{14}$.

\section{Makroekonomiczne uwarunkowania stosunków przemysłowych}

W 2007 r. tuż przed kryzysem gospodarczym przeciętny poziom PKB per capita w PPS w 11 analizowanych krajach EŚW stanowił 62\% średniego poziomu dla UE. Najlepszy wynik należał do Słowenii i Czech (odpowiednio 87\% i 82\%), zaś na ostatnim miejscu uplasowała się Bułgaria z wynikiem 40\%. Kryzys gospodarczy, który w różnym stopniu dotknął kraje EŚW, dokonał pewnej korekty w procesie konwergencji gospodarek tych krajów w tym obszarze. Największe spadki PKB odnotowano na Litwie, Łotwie i Estonii w 2009 r., z kolei w Czechach, Chorwacji i Słowenii spadek PKB utrzymywał się najdłużej ${ }^{15}$. Spowodowało to, że w krajach bałtyckich, Chorwacji i Słowenii odnotowano w okresie 2007-2010 ujemne zmiany we wskaźnikach PKB per capita w stosunku do średniej UE. Analizując okres 2007-2017, można zauważyć, że wszystkie analizowane kraje EŚW poza Słowenią poprawiły swoją pozycję względem średniej w UE, ale w bardzo różnym stopniu. Rumunia, Litwa i Polska zyskały odpowiednio po 19, 18 i 16 p.p., z kolei Bułgaria zaledwie o 4, a Czechy o 7 p.p., zaś w Chorwacji poziom ten nie uległ zmianie. Najlepszy wynik w 2017 r. nadal należał do Czech i Słowenii (odpowiednio 89\% i 85\%), a ostatnie miejsce wciąż zajmowała Bułgaria. Z kolei przeciętny poziom PKB per capita w 11 krajach EŚW wzrósł do $71 \%$ średniego poziomu dla UE.

TABELA 1: PKB per capita $w$ PPS

\begin{tabular}{|l|c|c|c|c|c|c|}
\hline \multicolumn{1}{|c|}{ Kraje } & 2004 & 2007 & 2010 & 2014 & 2017 & $\begin{array}{c}\text { Zmiana w p.p. w okresie } \\
\text { 2007-2017 }\end{array}$ \\
\hline 1 & 2 & 3 & 4 & 5 & 6 & 7 \\
\hline UE* $^{\prime}$ & 100 & 100 & 100 & 100 & 100 & - \\
\hline Bułgaria & 30 & 40 & 44 & 47 & 49 & 4 \\
\hline Chorwacja & 46 & 61 & 59 & 59 & 61 & 0 \\
\hline
\end{tabular}

Ibidem, s. 575-576.

15 Opracowanie na podstawie danych Eurostatu (Real GDP growth rate - volume); https://ec.europa.eu/eurostat 
Tabela 1 (cd.)

\begin{tabular}{|l|c|c|c|c|c|c|}
\hline \multicolumn{1}{|c|}{1} & 2 & 3 & 4 & 5 & 6 & 7 \\
\hline Czechy & 72 & 82 & 83 & 82 & 89 & 7 \\
\hline Estonia & 50 & 69 & 65 & 76 & 77 & 8 \\
\hline Litwa & 48 & 60 & 60 & 75 & 78 & 18 \\
\hline Lotwa & 43 & 57 & 53 & 63 & 67 & 10 \\
\hline Polska & 47 & 53 & 62 & 67 & 70 & 17 \\
\hline Rumunia & 32 & 44 & 51 & 55 & 63 & 19 \\
\hline Słowacja & 52 & 67 & 71 & 77 & 77 & 10 \\
\hline Słowenia & 78 & 87 & 85 & 82 & 85 & -2 \\
\hline Węgry & 61 & 60 & 65 & 68 & 68 & 8 \\
\hline
\end{tabular}

O b j a ś n i e n i a: *indeks (EU-28 = 100); dla 2004 r. (UE-25=100).

Źródło: opracowanie na podstawie danych Eurostatu (http://ec.europa.eu/eurostat); (PROD 2018-08-17); Eurostat News Release, 75/2005, 3 June 2005.

Przed kryzysem finansowym w 2007 r. stopa bezrobocia w grupie 11 analizowanych krajów EŚW wynosiła $8,1 \%$ i była wyższa w porównaniu ze stopą bezrobocia dla grupy krajów UE-15 (6,4\%) i UE-28 $(6,5 \%)^{16}$. Spośród krajów EŚW kryzys najmocniej uderzył w rynki pracy na Łotwie, Litwie i Estonii, powodując trzykrotny wzrost stopy bezrobocia w okresie 2007-2010 (tabela 2). Pozostałe kraje EŚW okazały się być bardziej odporne na skutki kryzysu. W przypadku Polski najwyższy wzrost stopy bezrobocia nastąpił w okresie 2009-2013 i wynosił zaledwie 2 p.p. Również w przypadku Rumunii i Czech zmiany stopy bezrobocia w kryzysie były niewielkie. W 2014 r. stopa bezrobocia dla grupy 11 krajów EŚW wynosiła 10\% i była nawet trochę niższa od stopy bezrobocia dla grupy krajów UE-15 (10,8\%) i całej UE $(10,6 \%)^{17}$. Należy się zgodzić z E. Kwiatkowskim ${ }^{18}$, że kryzys gospodarczy spowodował stosunkowo najmniejsze szkody na rynku pracy w grupie krajów EŚW. Następnie mię-

16 Obliczenia własne na podstawie danych Eurostatu (Unemployment rate - annual data), https://ec.europa.eu/eurostat

17 Ibidem.

18 E. Kwiatkowski, Bezrobocie w krajach Europy Środkowo-Wschodniej, w: P. Gabrielczak, L. Kucharski, E. Kwiatkowski, Rynki pracy w okresie globalnego kryzysu w krajach Europy Środkowo-Wschodniej, Wydawnictwo UŁ, Łódź 2016, s. 51. 
dzy rokiem 2014 a 2017 stopy bezrobocia spadły we wszystkich krajach UE. W 2017 r. najniższe stopy bezrobocia w grupie 11 krajów EŚW odnotowano w Czechach (2,9\%), Węgrzech (4,2\%), Polsce i Rumunii (4,9\%). Kontrastuje to z wysoką stopą bezrobocia w Chorwacji $(11,1 \%)$, ale przede wszystkim z wciąż ekstremalnie wysokimi stopami bezrobocia w dwóch krajach UE-15, tzn. w Grecji (21,5\%) i Hiszpanii (17,2\%).

TABELA 2: Stopa bezrobocia (w\%)

\begin{tabular}{|l|c|c|c|c|}
\hline \multicolumn{1}{|c|}{ Kraje } & 2007 & 2010 & 2014 & 2017 \\
\hline UE-28* & 6,5 & 10,2 & 10,6 & 7,6 \\
\hline UE-15* & 6,4 & 9,2 & 10,8 & 8,5 \\
\hline Bułgaria & 6,9 & 10,3 & 11,4 & 6,2 \\
\hline Chorwacja & 9,9 & 11,8 & 17,2 & 11,1 \\
\hline Czechy & 5,3 & 6,7 & 6,1 & 2,9 \\
\hline Estonia & 4,6 & 16,7 & 7,4 & 5,8 \\
\hline Litwa & 4,3 & 17,8 & 10,7 & 7,1 \\
\hline Lotwa & 6,1 & 19,5 & 10,8 & 8,7 \\
\hline Polska & 9,6 & 9,7 & 9,0 & 4,9 \\
\hline Rumunia & 6,4 & 7,0 & 6,8 & 4,9 \\
\hline Słowacja & 11,2 & 14,5 & 13,2 & 8,1 \\
\hline Słowenia & 4,9 & 7,3 & 9,7 & 6,6 \\
\hline Węgry & 7,4 & 11,2 & 7,7 & 4,2 \\
\hline
\end{tabular}

O b j a ś n i e n i a: * dla UE-28 i UE-15 obliczenia własne na podstawie danych Eurostatu. Źró dło: opracowanie na podstawie danych Eurostatu (http://ec.europa.eu/eurostat); (PROD 2018-08-17).

Przed kryzysem gospodarczym zauważalny był istotny postęp w procesie konwergencji gospodarek krajów EŚW w obszarze płac. W okresie 2000-2009 płace realne rosły najszybciej w krajach bałtyckich i Rumunii (rysunek 1). W krajach byłej ,piętnastki” wzrost ten był nawet kilkukrotnie niższy niż średnia dla 11 krajów EŚW. Kryzys wstrzymał ten proces konwergencji. M. Bernaciak wymienia cztery powody stagnacji płac w tym okresie: 1) cięcie kosztów (w tym wynagrodzeń) przez firmy; 2) osłabienie pozycji przetargowej związ- 
ków zawodowych; 3) spadek znaczenia czynników, które doprowadziły do wzrostu płac w okresie przedkryzysowym; 4) środki oszczędnościowe wprowadzone w sektorze publicznym w celu poprawy równowagi budżetowej ${ }^{19}$. Tylko w dwóch krajach EŚW (Bułgaria, Polska) wzrost płac realnych w okresie 2010-2017 przewyższał ten z okresu 2000-2009. W przypadku zaś Chorwacji odnotowano spadek płac realnych, choć był on ponad dwukrotnie niższy od największego spadku płac wśród krajów UE-15, tj. w Grecji $(-19,1 \%)^{20}$.

RYSUNEK 1: Wzrost płac realnych w krajach EŚW w okresie 2000-2009 i 2010-2017

-2000-2009 -2010-2017

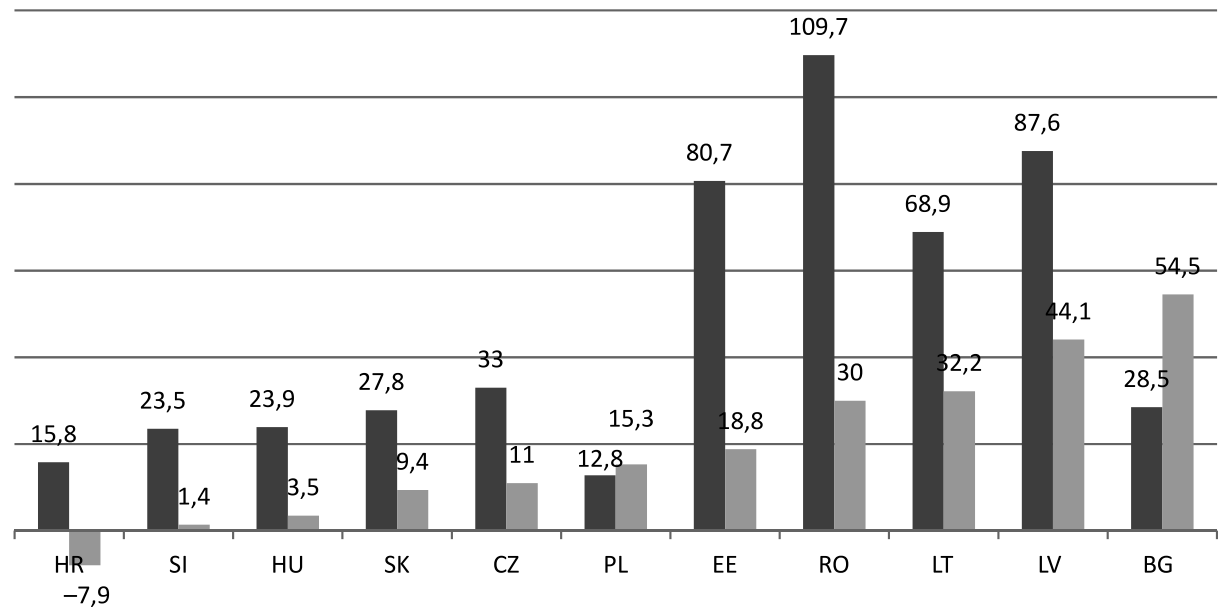

Ź ró d ł o: Bechmarking Working Europe 2018, ETUI, Brussels, s. 56.

Kryzys wstrzymał również proces konwergencji w obszarze płac nominalnych. W okresie 1995-2008 płace nominalne w krajach bałtyckich oraz w czterech krajach Europy Centralnej (Polska, Czechy, Węgry, Słowacja) wzrosły z poziomu $6-18 \%$ do poziomu $30-38,8 \%$ średniej dla krajów UE- $15^{21}$. Z kolei

19 M. Bernaciak, Beyond the CEE 'black box': crisis and industrial relations in the new EU member states, Working Paper 2015.05, ETUI, Brussels.

20 Zob. T. Müller, K. Vandaele, B. Galgóczi, Z. Rasnača, Wages and collective bargaining: a new attempt to ensure fair wages and adequate minimum wages, w: Bechmarking Working Europe 2018, ETUI, Brussels, s. 56.

21 Ibidem, s. 57. 
w okresie 2008-2017 ten wzrost dla tych krajów był znacznie wolniejszy, tzn. o 1,2-8,8 p.p. do poziomu 29,9-45,8\% średniej dla krajów UE-15. W przypadku Węgier, Chorwacji, Rumunii i Czech odnotowano nawet odwrócenie trendu w okresie 2008-2013 (w Chorwacji spadek ten był aż do 2017 r.). Ostatnie cztery lata przyniosły wzrost poziomu płac nominalnych w stosunku do średniej w krajach byłej ,"piętnastki” w prawie wszystkich analizowanych krajach EŚW (największy w Rumunii, Estonii, Łotwie i na Litwie), jednak różnica między tymi dwoma grupami krajów nadal pozostaje znaczna.

RYSUNEK 2: Poziom płac nominalnych jako \% średniej dla krajów UE15 (w EUR)

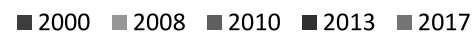

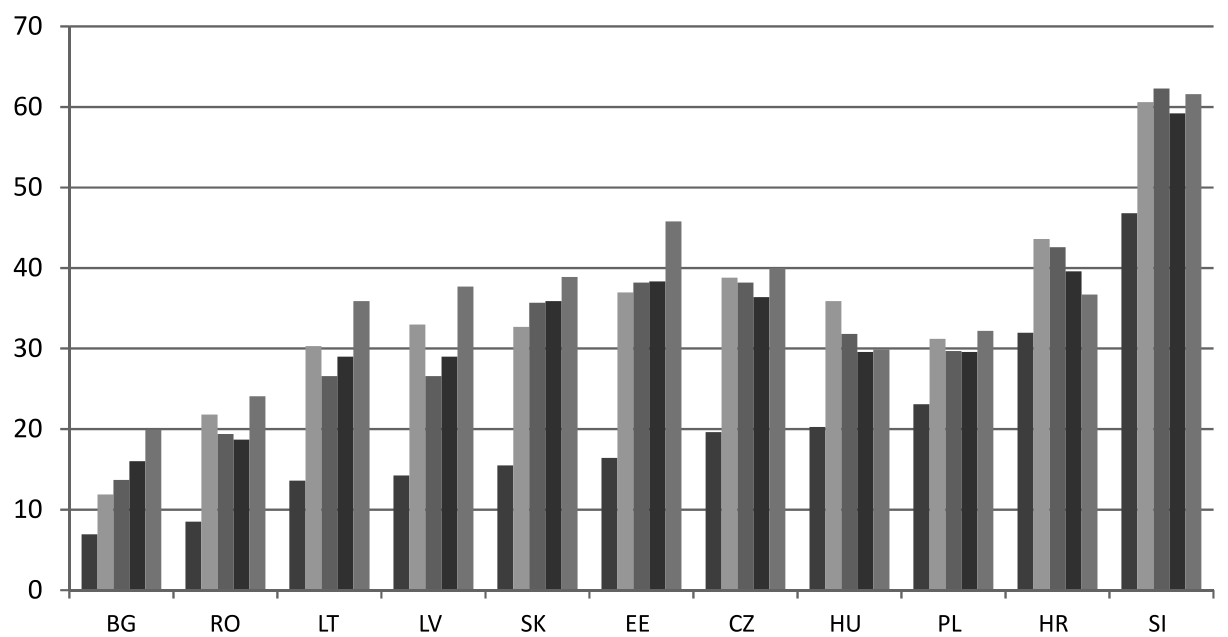

Ź ró dło: opracowanie na podstawie AMECO (http://ec.europa.eu); (Last Update 8 November 2018).

\section{Elementy składowe stosunków przemysłowych}

W 2016 r. średni zasięg umów zbiorowych dla 11 analizowanych krajów EŚW Europy wynosił zaledwie $28 \%$ w porównaniu do $71 \%$ średniego zasięgu umów dla krajów byłej „piętnastki”22. Najlepszy wynik wśród krajów EŚW osiągnęła Słowenia (65\%) i Chorwacja (46,7\%). Z kolei w przypadku Litwy, Łotwy i Buł-

22 Obliczenia własne na podstawie danych OECD, ILOSTAT (www.ilo.org) (Cypr) i ICTWSS database (Malta, Bułgaria, Rumunia). 
garii wskaźnik ten nie przekraczał 15\% (rysunek 3). Należy jednak zaznaczyć, że udział pracowników objętych umowami zbiorowymi w krajach EŚW był na niskim poziomie jeszcze przed przystąpieniem tych krajów do UE. W 2003 r. średni zasięg umów zbiorowych dla dziesięciu krajów EŚW (poza Chorwacją) wynosił 44\%. W tym samym roku kraje UE-15 osiągnęły średni wynik na poziomie 77,5\%. Wśród krajów EŚW jedynie w Rumunii i Słowenii wskaźnik ten przekraczał (i to znacznie) średni poziom dla $\mathrm{UE}^{23}$. Kryzys gospodarczy nie przyspieszył konwergencji w tym obszarze, a w przypadku niektórych krajów EŚW jeszcze bardziej pogłębił te różnice. Największe spadki w tym wskaźniku stosunków przemysłowych w okresie kryzysu odnotowano w Rumunii (ponad 60 p.p.), Słowenii (ok. 30 p.p.), Słowacji i na Węgrzech (ok. 15 p.p.). Przeprowadzone wówczas reformy przyczyniły się do decentralizacji umów zbiorowych, deregulacji rynku pracy i osłabienia związków zawodowych. Przykładowo uchwalona w 2011 r. w Rumunii nowa ustawa (tzw. Social Dialogue Act) przekształciła gruntownie system umów zbiorowych w tym kraju, znosząc automatyczne rozszerzanie umów zbiorowych, pozostawiając w mocy istniejące umowy na poziomie sektorowych jedynie do terminu ich wygaśnięcia i ograniczając prawo do strajku ${ }^{24}$. W Słowenii kryzys zintensyfikował dokonujące się od połowy lat 2000. zmiany w systemie stosunków przemysłowych ${ }^{25}$, doprowadzając m.in. do obniżenia o dwa stopnie dominującego poziomu zawierania umów zbiorowych, zmniejszenia ze 100 do $60 \%$ wskaźnika zrzeszania się pracodawców, obniżenia o prawie 30 p.p. zasięgu umów zbiorowych. Jak twierdzi B. Greskovits, instytucje umów zbiorowych przypominają w krajach EŚW zdewastowany krajobraz ${ }^{26}$. Obecnie wśród analizowanych 11 krajów EŚW jednie w Słowenii zasięg umów zbiorowych przekracza średni poziom dla UE-28 (zob. rysunek 3).

Duże dysproporcje między krajami EŚW i krajami UE-15 występują również w przypadku poziomu uzwiązkowienia. W 2016 r. średnio 14\% pracowników należało do związków zawodowych w pierwszej grupie krajów w porównaniu do $32 \% \mathrm{w}$ drugiej grupie ${ }^{27}$. Jednak między poszczególnymi krajami EŚW nie ma zaś aż takich różnic jak w przypadku zasięgu umów zbiorowych.

23 Ibidem. Analiza dotyczy wszystkich 27 krajów (brak danych dla Chorwacji).

24 M. Bernaciak, op. cit., s. 21-22.

25 Zob. M. Stanojevič, M. Klarič, The impact of socio-economic shocks on social dialogue in Slovenia, Transfer 2013/19 (2).

26 B. Greskovits, op. cit., s. 275.

27 Obliczenia własne na podstawie danych OECD, ILOSTAT (www.ilo.org) (Malta, Cypr) i ICTWSS database (Bułgaria, Rumunia, Chorwacja). Analiza dotyczy wszystkich 28 krajów. 
RYSUNEK 3: Zasięg umów zbiorowych w krajach EŚW (w \%)

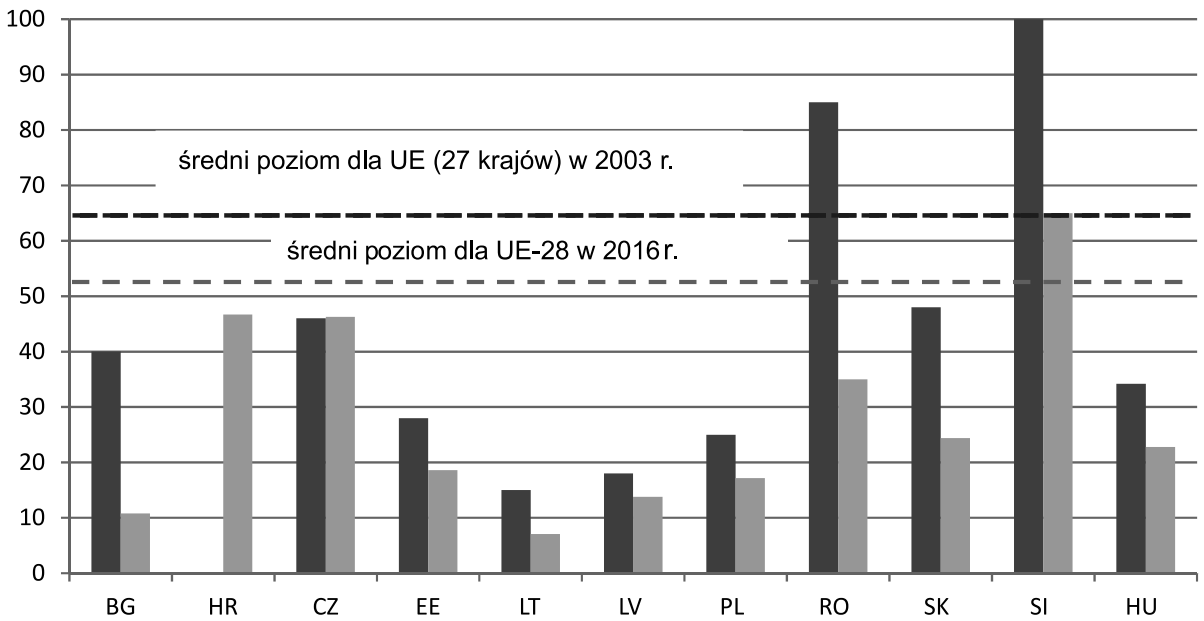

Ź r ó d ł o: opracowanie na podstawie danych OECD (https://stats.oecd.org/), ILO STAT (www. ilo.org), ICTWSS database (http://uva-aias.net/en/ictwss). Średnie poziomy dla UE w 2003 r. i 2016 r. - obliczenia własne.

Najwyższy poziom uzwiązkowienia ma Chorwacja $(25,8 \%)$, Słowenia $(26,9 \%)$ i Rumunia (25,2\%). Z kolei w Estonii, na Litwie oraz Węgrzech mniej niż 10\% pracowników jest „uzwiązkowionych” (rysunek 4). Przed wejściem do UE średni poziom uzwiązkowienia dla analizowanych 11 krajów EŚW wyniósł 24,7\% w 2003 r., zaś w krajach UE-15 - prawie 38\%. Wśród krajów EŚW jedynie w Rumunii, Słowenii i Chorwacji wskaźnik ten przekraczał średni poziom dla $\mathrm{UE}^{28}$. W okresie kryzysu największy spadek w poziomie uzwiązkowienia wśród krajów EŚW odnotowano w Rumunii (o 11 p.p.), zaś ustawa z 2011 r. zmniejszyła ochronę liderów związkowych w tym kraju. Również na Węgrzech nowy kodeks pracy z 2012 r. osłabił pozycję związków zawodowych w zakładzie pracy poprzez zmniejszenie liczby liderów związkowych z gwarantowaną ochroną prawną. Ponadto nowy kodeks upoważniał rady zakładowe do negocjowania porozumień na poziomie zakładu pracy, dając pracodawcom możliwość tworzenia „marionetkowych” $\operatorname{rad}^{29}$. Obecnie wśród analizowanych 11 krajów

\section{Ibidem.}

29 I. Szabo, Between polarization and statism: Effects of the crisis on collective bargaining processes and outcomes in Hungary, Transfer 2013/19 (2), s. 211. 
EŚW jednie w Słowenii poziom uzwiązkowienia nieznacznie przekracza, a w przypadku Chorwacji i Rumunii jest zbliżony do średniego poziomu dla UE-28 (zob. rysunek 4).

RYSUNEK 4: Poziom uzwiazkowienia w krajach EŚW (w \%)

— $2003 \square 2016$

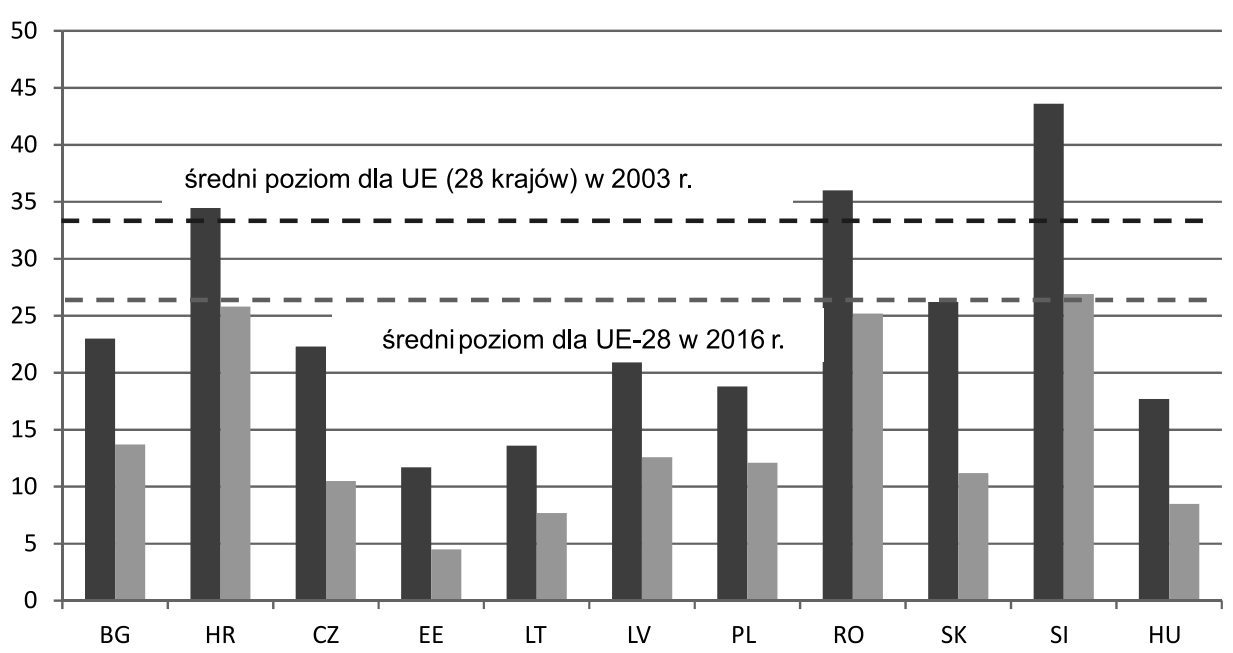

Źr ódło: opracowanie na podstawie danych OECD (https://stats.oecd.org), ILO STAT (www. ilo.org), ICTWSS database (http://uva-aias.net/en/ictwss). Średnie poziomy dla UE w 2003 r. i 2016 r. - obliczenia własne.

Dyrektywa unijna 2002/14/EC była namacalnym wyrazem konwergencji stosunków przemysłowych w UE w obszarze partycypacji pracowniczej na poziomie przedsiębiorstwa. Jak wskazuje G. Meardi jej implementacja miała mieć zdecydowanie większy wpływ na postkomunistyczne kraje EŚW niż stare kraje Unii, gdyż w większości z nich (poza Węgrami i Słowenią) związki zawodowe były jedyną formą reprezentacji pracowniczej ${ }^{30}$. Należy zaznaczyć, że wdrożenie dyrektywy i tym samym utworzenie rad zakładowych w przedsiębiorstwach EŚW spowodowało przekształcenie na ogół występującego w tych krajach monistycznego systemu reprezentacji w system dualny (rady i związki) lub w przy-

30 G. Meardi, The fate of the 'hard' and 'soft' acquits communautaires in the new member states, w: V. Delteil, V. Kirov (eds.), Labour and Social Transformation in Central and Eastern Europe, Routledge, New York 2017, s. 128. 
padku Litwy i Rumunii - system monistyczny ,alternatywny” (albo związkowi reprezentanci albo rady). Jednak jak pokazują badania ${ }^{31}$, nowe instytucje partycypacji napotkały na wiele instytucjonalnych, organizacyjnych i strukturalnych przeszkód, które spowodowały, że nie stały się one efektywnymi formami reprezentacji pracowników, ich zasięg jest niewielki i pełnią one na ogół funkcję informacyjną.

Członkowie rad w krajach EŚW są wybierani na okres od 3 do 5 lat. W przypadku Łotwy prawo nie określa długości kadencji, a przedstawiciele pracowników są wybierani przez większość załogi na tzw. „określony czas”. Węgry, Polska, Słowacja i Bułgaria ustanowiły najwyższe ,progi zatrudnienia” w tworzeniu rad (tabela 3), uniemożliwiając w ten sposób wybór reprezentacji pracowniczej dla zdecydowanej większości pracowników. Ustawa w trzech innych krajach EŚW ma zastosowanie bez względu na rozmiar przedsiębiorstwa z tym, że pewne uprawnienia rad w Estonii (tzw. employees' trustees) są wyraźnie wskazane dla przedsiębiorstw zatrudniających przynajmniej 30 pracowników, a w czeskich przedsiębiorstwach zatrudniających mniej niż 10 osób - reprezentacja załogi nie ma prawa do informacji na temat sytuacji ekonomicznej i działalności firmy oraz jej wpływu na środowisko. Z kolei na Łotwie, w Rumunii i Bułgarii w zasadzie nie ma stricte instytucji rad zakładowych, ale ich funkcje wynikające z dyrektywy pełnią tzw. upoważnieni przedstawiciele pracowników $^{32}$. W przypadku Słowenii i Węgier uprawnienia rad są rozszerzone (poza informację i konsultację) na prawo do współdecydowania w kilku kwestiach dotyczących polityki socjalnej. Ponadto w pięciu analizowanych krajach rady otrzymały możliwość zawierania porozumień zbiorowych na poziomie przedsiębiorstwa. W przypadku Łotwy i Estonii dotyczy ono tylko przedsiębiorstw, w których nie ma związkowych reprezentantów. W wyniku zmian w kodeksie pracy również w Słowacji rady zakładowe otrzymały w 2012 r. prawo do negocjowania umów zbiorowych pod warunkiem, że w zakładzie pracy nie funkcjonowały związki zawodowe. Jednak po roku nowy rząd pod naciskiem związków usunął ten zapis z kodeksu pracy ${ }^{33}$. Na Węgrzech prawo rad do zawierania umów zbiorowych na poziomie zakładu pracy zostało wprowadzone dopiero

31 Zob. m.in. K. Skorupińska, The failure of a new form of employee representation: Polish works councils in comparative perspective, European Journal of Industrial Relations 2018/24 (2); R. Blanipain, N. Lyutov (eds.), Workers'Representation in Central and Eastern Europe, Wolter Kluwer, Alphen on the Rhine 2014.

32 L. Fulton, Worker representation in Europe, Labour Research Department and ETUI, 2015; www.worker-participation.eu

33 Ibidem. 
w 2012 r. W przypadku Litwy rady na poziomie przedsiębiorstwa mają takie same uprawnienia jak związki, w tym prawo do zawierania umów zbiorowych jak również do organizowania strajków ${ }^{34}$.

TABELA 3: Rady zakładowe w krajach EŚW

\begin{tabular}{|c|c|c|c|c|c|}
\hline Kraj & $\begin{array}{c}\text { Obecność } \\
\text { w zakładzie } \\
\text { pracy }\end{array}$ & $\begin{array}{c}\text { Próg } \\
\text { ustawowy }\end{array}$ & Uprawnienia & $\begin{array}{l}\text { Zawieranie } \\
\text { porozumień } \\
\text { zbiorowych }\end{array}$ & Kadencja \\
\hline Węgry & $\mathrm{X}$ & 51 & $\begin{array}{c}\mathrm{A}+\mathrm{B}+\mathrm{C} \\
\text { (fundusz socjalny) }\end{array}$ & Tak & 5 lat \\
\hline Czechy & $\mathrm{X}$ & brak & $\mathrm{A}+\mathrm{B}$ & Nie & 3 lata \\
\hline Polska & $\mathrm{X}$ & 50 & $A+B$ & $\mathrm{Nie}$ & 4 lata \\
\hline Słowacja & $\mathrm{X}$ & 50 & $\mathrm{~A}+\mathrm{B}$ & Nie & 4 lata \\
\hline Słowenia & X & 21 & $\begin{array}{c}\mathrm{A}+\mathrm{B}+\mathrm{C} \text { (coroczne } \\
\text { urlopy, kryteria oceny } \\
\text { pracowników, zaplecze } \\
\text { socjalne) }\end{array}$ & Nie & 4 lata \\
\hline Łotwa & $\mathrm{X}$ & brak & $A+B$ & Tak* & brak \\
\hline Litwa & $\mathrm{X}^{*}$ & 20 & $A+B$ & $\begin{aligned} & \text { Tak } \\
+ & \text { strajki }\end{aligned}$ & 3 lata \\
\hline Estonia & $\mathrm{X}$ & $\begin{array}{l}\text { brak (na } \\
\text { ogół 30) }\end{array}$ & $\mathrm{A}+\mathrm{B}$ & Tak* & 3 lata \\
\hline Bułgaria & $\mathrm{X}$ & $50 / 20$ & $\mathrm{~A}+\mathrm{B}$ & Nie & 1-3 lata \\
\hline Rumunia & $\mathrm{X}^{*}$ & 21 & $\mathrm{~A}+\mathrm{B}$ & Nie & 2 lata \\
\hline Chorwacja & $\mathrm{X}$ & 20 & $\mathrm{~A}+\mathrm{B}$ & $\mathrm{Tak}^{* *}$ & 3 lata \\
\hline
\end{tabular}

O b j a śn i e n i a: $\mathrm{X}^{*}$ - pod warunkiem, że w przedsiębiorstwie nie ma związkowych reprezentantów; Tak* - pod warunkiem, że w przedsiębiorstwie nie ma związkowych reprezentantów; Tak** - pod warunkiem, że kwestie będące przedmiotem porozumienia nie dotyczą wynagrodzenia, czasu pracy czy innych spraw z reguły negocjowanych przez związki zawodowe; A - informacja, B - konsultacja, C - współdecydowanie.

Źr ó dło: opracowanie własne.

34 D. Petrylaité, Workers representation in Lithuania: Works councils' role, w: R. Blanpain, N. Lyutov (eds.), op. cit., s. 139-150. 
Tabela 4 przedstawia zasady konstrukcji indeksu partycypacji pracowniczej (IPP) dla krajów Europy Środkowo-Wschodniej, które czerpią inspirację z przeglądu literatury na temat stosunków przemysłowych i opierają się na European Participation Index (EPI) przedstawionym przez N. Kluge, M. Stollta i S. Vitolsa $\mathrm{w} 2010 \mathrm{r}^{35}$. IPP dla EŚW bazuje na tych samych trzech głównych wymiarach wyodrębnionych $w$ ramach EPI, jedynie nieznacznie zmodyfikowanych, tzn. (A) partycypacja związkowa, (B) partycypacja pracownicza na poziomie przedsiębiorstwa w postaci rad zakładowych i (C) reprezentacja pracownicza w organach nadzoru. W przypadku wymiaru A i B wyodrębniono także zmienne składowe $\left(\mathrm{A}_{1}, \mathrm{~A}_{2}, \mathrm{~B}_{1}, \mathrm{~B}_{2}\right.$ i $\left.\mathrm{B}_{3}\right)$. Każdej ze zmiennych składowych Autorka przyporządkowała kilka wariantów przedstawiających formy (rozwiązania) przyjmowane przez tę zmienną. Są to warianty dostosowane do krajów EŚW, gdyż celem konstrukcji indeksu było porównanie siły ,pracowniczego głosu” w tej grupie krajów. Następnie dokonano określenia znaczenia poszczególnych wariantów odpowiadających zmiennym $\mathrm{A}_{1}, \mathrm{~A}_{2}, \mathrm{~B}_{1}, \mathrm{~B}_{2}, \mathrm{~B}_{3}$ i C. Każdemu wariantowi Autorka przyporządkowała zatem określoną liczbę punktów według skali od 0 do 2 . W przypadku zmiennych składowych $\mathrm{B}_{2} \mathrm{~B}_{3}$ oraz $\mathrm{C}$ zaproponowano trzy wersje odpowiedzi z możliwą punktacją 0,1 i 2 . Z kolei w przypadku zmiennych składowych $\mathrm{A}_{1}, \mathrm{~A}_{2}$ i $\mathrm{B}_{1}$ przedstawiono pięć możliwych wersji odpowiedzi z następującą punktacją: $0,1 / 2,1,3 / 2$ i 2 .

TABELA 4: Konstrukcja indeksu partycypacji pracowniczej dla krajów EŚW

\begin{tabular}{|l|c|}
\hline \multicolumn{1}{|c|}{ Wymiary partycypacji i zmienne składowe } & Liczba punktów \\
\hline \multicolumn{1}{|c|}{1} & 2 \\
\hline A. Partycypacja związkowa & \\
\hline A $_{1 .}$ Poziom uzwiązkowienia: & 0 \\
\hline - mniej niż 5\% & $1 / 2$ \\
\hline - 5-10\% & 1 \\
\hline - $10-15 \%$ & $3 / 2$ \\
\hline - $15-20 \%$ & \\
\hline
\end{tabular}

35 Zob. S. Vitols, The European Participation Index (EPI): A Tool for Cross-National Quantitative Comparison, Background paper, ETUI, October 2010; J. Viser, Data Base on Institutional Characteristics of Trade Unions, Wage Setting, State Intervention and Social Pacts, 1960-2014 (ICTWSS), Version 5.0, Amsterdam Institute for Advanced labor Studies, October 2015. 
Tabela 4 (cd.)

\begin{tabular}{|c|c|}
\hline 1 & 2 \\
\hline - więcej niż $20 \%$ & 2 \\
\hline \multicolumn{2}{|l|}{$\mathrm{A}_{2 .}$ Zasięg umów zbiorowych: } \\
\hline - mniej niż $10 \%$ & 0 \\
\hline - $10-25 \%$ & $1 / 2$ \\
\hline - $25-40 \%$ & 1 \\
\hline - $40-55 \%$ & $3 / 2$ \\
\hline - więcej niż 55\% & 2 \\
\hline \multicolumn{2}{|l|}{$\begin{array}{l}\text { B. Partycypacja pracownicza na poziomie przedsiębiorstwa w postaci } \\
\text { rad zakładowych }\end{array}$} \\
\hline \multicolumn{2}{|l|}{$\mathrm{B}_{1}$ Obecność rad zakładowych i ich potencjalny zasięg: } \\
\hline - brak reprezentacji pracowniczej & 0 \\
\hline $\begin{array}{l}\text { funkcje rad zakładowych pełnią upoważnieni przedstawiciele pracow- } \\
\text { ników lub rady zakładowe funkcjonują pod warunkiem, że w przed- } \\
\text { siębiorstwie nie ma związkowych reprezentantów; próg ustawowy } \\
-50 \text { pracowników }\end{array}$ & $1 / 2$ \\
\hline $\begin{array}{l}\text { funkcje rad zakładowych pełnią upoważnieni przedstawiciele } \\
\text { pracowników lub rady zakładowe funkcjonują pod warunkiem, że } \\
\text { w przedsiębiorstwie nie ma związkowych reprezentantów; brak progu } \\
\text { ustawowego lub próg - } 20 \text { pracowników }\end{array}$ & 1 \\
\hline $\begin{array}{l}\text { - rady funkcjonują w przedsiębiorstwie bez względu na obecność } \\
\text { związkowych reprezentantów; próg ustawowy - } 50 \text { pracowników }\end{array}$ & $3 / 2$ \\
\hline $\begin{array}{l}\text { - rady funkcjonują w przedsiębiorstwie bez względu na obecność } \\
\text { związkowych reprezentantów; brak progu ustawowego lub próg } \\
-20 \text { pracowników }\end{array}$ & 2 \\
\hline \multicolumn{2}{|l|}{$\mathrm{B}_{2 .}$ Uprawnienia rad zakładowych: } \\
\hline - brak uprawnień & 0 \\
\hline - informowanie i konsultacja & 1 \\
\hline - informowanie, konsultacja i współdecydowanie & 2 \\
\hline \multicolumn{2}{|l|}{$\mathrm{B}_{3}$.Zawieranie porozumień zbiorowych na poziomie przedsiębiorstwa: } \\
\hline - brak możliwości & 0 \\
\hline
\end{tabular}




\begin{tabular}{|l|c|}
\hline \multicolumn{1}{|c|}{1} & 2 \\
\hline - & $\begin{array}{l}\text { tak, ale pod warunkiem, że w przedsiębiorstwie nie ma związkowych } \\
\text { reprezentantów lub kwestie będące przedmiotem porozumienia nie } \\
\text { dotyczą spraw z reguły negocjowanych przez związki zawodowe }\end{array}$ \\
\hline - tak & 2 \\
\hline C. Reprezentacja pracownicza w organach nadzoru: & 0 \\
\hline - $\begin{array}{l}\text { brak ustawodawstwa lub innych uzgodnień zapewniających taką } \\
\text { reprezentację }\end{array}$ & 1 \\
\hline - $\begin{array}{l}\text { reprezentacja w organach nadzoru jest ograniczona do przedsię- } \\
\text { biorstw państwowych lub w trakcie prywatyzacji }\end{array}$ & 2 \\
\hline $\begin{array}{l}\text { reprezentacja w organach nadzoru przedsiębiorstw prywatnych i pań- } \\
\text { stwowych }\end{array}$ & \multicolumn{2}{|c|}{} \\
\hline
\end{tabular}

Źródło: opracowanie własne.

Indeks partycypacji pracowniczej (IPP) jest średnią arytmetyczną punktów uzyskanych przez trzy wymiary partycypacji, z których każdy jest średnią arytmetyczną ich zmiennych składowych. Punktacja dotycząca wymiaru A jest wyznaczona na podstawie danych OECD, ILO STAT i ICTWSS database (zob. rysunek 3 i 4), zaś źródło wyznaczenia punktacji dotyczącej wymiaru B stanowiła tabela 3 i Code Book dla ICTWSS database. Wyniki dla ostatniego wymiaru (tzn. ,reprezentacja pracownicza w organach nadzoru”) zostały opracowane na podstawie MAP: Board-level representation in the European Economic Area. Board level representation in Europe: overview in $2017^{36}$. Najnowsza zmiana w tym ostatnim przypadku nastąpiła w stosunku do Czech, gdzie odpowiednie regulacje w styczniu 2017 r. przywróciły reprezentację pracowników w organach nadzoru w sektorze prywatnym (zob. tabela 5).

$$
\mathbf{I P P}=\frac{1}{3}\left(\frac{A_{1}+A_{2}}{2}+\frac{B_{1}+B_{2}+B_{3}}{3}+\mathbf{C}\right)
$$

36 www.worker-participation.eu 
TABELA 5: Indeks partycypacji pracowniczej dla krajów EŚW

\begin{tabular}{|l|c|c|c|c|}
\hline \multicolumn{1}{|c|}{ Kraj } & Wymiar A & Wymiar B & Wymiar C & IPP \\
\hline Węgry & 0,5 & 1,83 & 2 & 1,44 \\
\hline Czechy & 1,25 & 1 & 2 & 1,41 \\
\hline Polska & 0,75 & 0,83 & 2 & 0,86 \\
\hline Słowacja & 0,75 & 0,83 & 2 & 1,19 \\
\hline Słowenia & 2 & 1,33 & 0 & 1,78 \\
\hline Lotwa & 0,75 & 1 & 0 & 0,58 \\
\hline Litwa & 0,25 & 1,33 & 0 & 0,53 \\
\hline Estonia & 0,25 & 1,33 & 0 & 0,53 \\
\hline Bułgaria & 0,75 & 0,67 & 0 & 0,47 \\
\hline Rumunia & 1,5 & 0,67 & 2 & 0,72 \\
\hline Chorwacja & 1,75 & 1,33 & 1,69 \\
\hline
\end{tabular}

Ź r ó d ł o: obliczenia własne.

Na rysunku 5 przedstawiono wartości indeksu partycypacji pracowniczej dla 11 analizowanych krajów EŚW. Wartość IPP waha się od 0,47 w Bułgarii do 1,78 w Słowenii. Do grupy krajów z silniejszym „,pracowniczym głosem” (indeks IPP powyżej 1) należy również Chorwacja, Węgry, Czechy i Słowacja. Wysoka wartość IPP w przypadku Słowenii i Chorwacji jest spowodowana przede wszystkim najwyższymi poziomami zasięgu umów zbiorowych i „uzwiązkowienia” wśród krajów EŚW. Dodatkowo w krajach tych (podobnie jak w trzech pozostałych wymienionych) pracownicy mają ustawową reprezentację w organach nadzoru zarówno w przedsiębiorstwach prywatnych, jak i państwowych. Z kolei w przypadku czterech krajów z najniższymi wartościami IPP (poniżej 0,6) brak jest ustawodawstwa lub innych regulacji zapewniających taką reprezentację. Ponadto Litwa i Estonia mają najniższe wskaźniki w obszarze „partycypacji związkowej”, zaś w Bułgarii siła „pracowniczego głosu” na poziomie przedsiębiorstwa jest najniższa (podobnie jak w Rumunii). 
RYSUNEK 5: Indeks partycypacji pracowniczej dla krajów EŚW

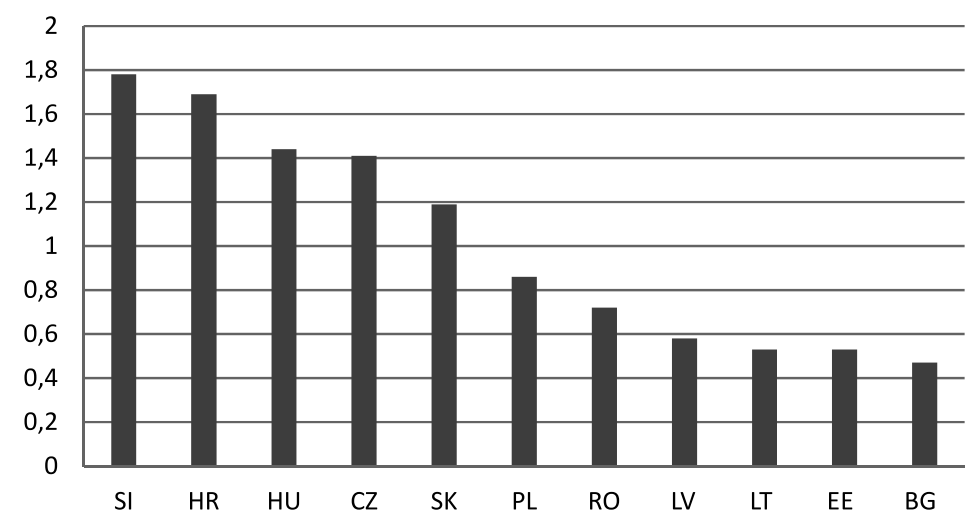

Źró d ło: opracowanie własne na podstawie tabeli 5.

\section{Zakończenie}

Słabość stosunków przemysłowych w krajach EŚW w porównaniu do krajów UE-15 jest nadal znaczna. Początkowy proces szybkiego nadrabiania zaległości (,,catching-up" process) w tym obszarze spowolnił w okresie kryzysu. Potwierdza to indeks standardów pracy i stosunków przemysłowych dla UE-28 ${ }^{37}$ opracowany przez H. Kohla. W okresie 2006-2010 nastąpił wzrost wartości tego indeksu (zob. tabela 6) we wszystkich krajach EŚW (poza Słowenią), co było głównie spowodowane implementacją dyrektywy unijnej 2002/14/EC, dotyczącej informacji i konsultacji pracowników oraz dostosowaniem dialogu społecznego do standardów europejskich ${ }^{38}$. Istotny postęp w procesie konwergencji gospodarek krajów EŚW był zauważalny również w obszarze płac (rysunek 1 i 2) i wzrostu PKB per capita (tabela 1). Mimo że dyrektywa 2002/14/EC była krokiem milowym w kierunku konwergencji stosunków przemysłowych w zakresie instytucjonalnej partycypacji pracowniczej, jednak w praktyce funkcjonowanie rad zakładowych nie spełniło wcześniejszych oczekiwań. Przeprowadzone w całej Europie w okresie kryzysu reformy i wprowadzone środki oszczędnościowe doprowadziły do istotnego obniżenia zasięgu umów zbiorowych w krajach EŚW (rysunek 3) (największe spadki w Rumunii i Słowenii),

37 Indeks ten składa się z 18 zmiennych składowych pogrupowanych w trzy obszary, tzn. indywidualne prawo pracy, zbiorowe prawo pracy i monitorowanie wdrażania prawa pracy.

38 H. Kohl, Convergence..., s. 285-311. 
decentralizacji tych umów i obniżenia poziomu uzwiązkowienia (rysunek 4). Spowodowało to także, że różnice między wyodrębnionymi przez D. Bohle i B. Greskovits trzema modelami tych stosunków w krajach EŚW zaczęły się zmniejszać. Można się zgodzić z B. Greskovits, że „aktorzy stosunków przemysłowych z tej grupy krajów weszli do Unii słabi, a od czasu jej rozszerzenia jeszcze bardziej się osłabili" ${ }^{39}$. Zmiany te potwierdza obniżenie się w $2013 \mathrm{r}$. wartości indeksu Kohla w sześciu krajach EŚW (tabela 6).

TABELA 6: Indeks standardów pracy i stosunków przemysłowych

\begin{tabular}{|c|c|c|c|c|c|c|c|c|c|c|c|c|}
\hline & RO & LV & BG & PL & LT & EE & HR & CZ & HU & SK & SI & $\begin{array}{c}\text { Średni poziom } \\
\text { dla UE-28 }\end{array}$ \\
\hline 2006 & 51 & 50 & 49 & 49 & 50 & 59 & 62 & 59 & 66 & 62 & 79 & 68 \\
\hline 2010 & 56 & 53 & 55 & 56 & 54 & 60 & 64 & 65 & 68 & 67 & 79 & 69 \\
\hline 2013 & 52 & 52 & 54 & 55 & 56 & 59 & 64 & 65 & 67 & 67 & 79 & 67,5 \\
\hline
\end{tabular}

Źr ó dło: H. Kohl, Convergence and divergence - 10 years since EU enlargement, Transfer 2015/21 (3), s. 288 (obliczenia własne dla średniego poziomu UE-28).

RYSUNEK 6: Zależność między Indeksem Partycypacji Pracowniczej a wspótczynnikiem Giniego dla krajów EŚW ${ }^{40}$

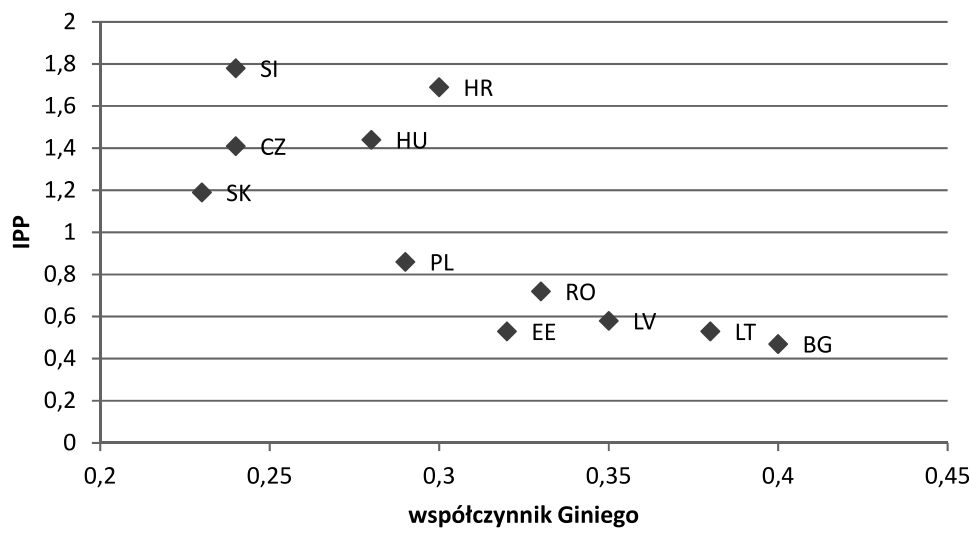

Źródło: opracowanie na podstawie: IPP dla krajów EŚW (rysunek 5); współczynnik Giniego dla 2017 r. (Eurostat http://ec.europa.eu/eurostat).

\section{B. Greskovits, op. cit., s. 272.}

40 Koncepcja rysunku oparta na rys. 5.11 w Bechmarking Working Europe 2018, s. 76. 
Pomimo upodabniania się elementów składowych stosunków przemysłowych, zróżnicowanie między krajami EŚW w tym obszarze jest nadal znaczne. Najwyższy zasięg umów zbiorowych i jednocześnie najwyższy poziom „uzwiązkowienia” przekraczający średni poziom dla UE-28 spotkać można jedynie w Słowenii. Kraj ten ma również najwyższą wartość indeksu partycypacji pracowniczej (IPP), która prawie czterokrotne przewyższa wartość tego indeksu dla Bułgarii. Niska siła ,pracowniczego głosu” w Bułgarii koresponduje z najniższym wśród krajów EŚW poziomem płac nominalnych jako procent średniej dla UE-15 (rysunek 2). Polska plasuje się dokładnie w środku uszeregowania krajów EŚW pod względem IPP. Poziom partycypacji związkowej oraz partycypacji pracowniczej w postaci rad zakładowych wygląda w tym kraju tak samo jak w Słowacji, ale reprezentacja pracownicza w organach nadzoru jest w Polsce ograniczona do przedsiębiorstw państwowych oraz w trakcie prywatyzacji.

Silną zależność między siłą ,pracowniczego głosu” wyrażoną przez indeks partycypacji pracowniczej a nierównością dochodową wyrażoną za pomocą współczynnika Giniego można zaobserwować na rysunku 6. W krajach z najwyższą wartością IPP (Słowenia, Czechy, Węgry) poziom nierówności dochodowej jest najmniejszy. Z kolei na drugim krańcu skali mamy Bułgarię i Łotwę z najniższymi standardami stosunków przemysłowych w obszarze partycypacji pracowniczej, w których poziom nierówności dochodowych jest jednocześnie największy. Wskazuje to, że wyższy poziom partycypacji (głównie związkowej) i wyższe standardy pracy (tabela 6) przyczyniają się do obniżenia nierówności dochodowych. Na zależność między wyższymi wskaźnikami ochrony zatrudnienia (indeks EPL) i częstszymi praktykami umów zbiorowych a niższym poziomem nierówności dochodowych wskazywała także M. Lissowska w swojej pracy The financial crisis and changing labour markets in post-transition countries. W przypadku Polski w okresie ostatnich dziecięciu lat można zaobserwować stopniowe obniżanie się nierówności dochodowych wyrażonych za pomocą współczynnika Giniego: z 0,32 w 2008 r, poprzez 0,307 w 2013 r., do 0,29 w 2017 r. Z kolei w Słowenii, gdzie w okresie kryzysu w największym stopniu osłabieniu uległy elementy stosunków przemysłowych (zgodnie z zależnością zaobserwowaną na rysunku 6), jednocześnie nastąpił wzrost współczynnika Giniego w okresie 2009-2014. 


\section{Bibliografia}

\section{Opracowania}

Bechmarking Working Europe 2018, ETUI, Brussels 2018.

Bernaciak Magdalena, Beyond the CEE 'black box': crisis and industrial relations in the new EU member states, Working Paper 2015.05, ETUI, Brussels.

Blanipain Roger, Lyutov Nikita (eds.), Workers'Representation in Central and Eastern Europe, Wolter Kluwer, Alphen on the Rhine 2014.

Bohle Dorothee, Greskovits Béla, Capitalist Diversity on Europe's Periphery, Cornell University Press, New York 2012.

Dunlop John T., Industrial Relations System, H. Holt and Company, New York 1958.

Eurostat News Release, 75/2005 3 June 2005.

Fulton Lionel, Worker representation in Europe, Labour Research Department and ETUI, 2015.

Glassner Vera, Central and Eastern European industrial relations in the crisis: National divergence and path-dependent change, Transfer 2013/19 (2).

Greskovits Béla, Ten years of enlargement and the forces of labour in Central and Eastern Europe, Transfer 2015/21 (3).

Hyman Richard, What future for industrial relations in Europe?, Employee Relations 2018/40 (2).

Kohl Heribert, Convergence and divergence - 10 years since EU enlargement, Transfer 2015/21 (3).

Kohl Heribert, Platzer Hans-Wolfgang, Industrial Relations in Central and Eastern Europe: A Comparison of Eight New EU Member States, ETUI, Brussels 2004.

Kwiatkowski Eugeniusz, Bezrobocie w krajach Europy Środkowo-Wschodniej, w: Piotr Gabrielczak, Leszek Kucharski, Eugeniusz Kwiatkowski, Rynki pracy w okresie globalnego kryzysu w krajach Europy Środkowo-Wschodniej, Wydawnictwo UŁ, Łódź 2016.

Lissowska Maria, The financial crisis and changing labour markets in post-transition countries, European Journal of Industrial Relations 2017/23 (1).

Meardi Guglielmo, The fate of the 'hard' and 'soft' acquits communautaires in the new member states, w: Violaine Delteil, Vassil Kirov (eds.), Labour and Social Transformation in Central and Eastern Europe, Routledge, New York 2017.

Müller Torsten, Vandaele Kurt, Galgóczi Béla, Rasnača Zane, Wages and collective bargaining: a new attempt to ensure fair wages and adequate minimum wages, w: Bechmarking Working Europe 2018, ETUI, Brussels.

Nölke Andreas, Vliegenthart Arjan, Enlarging the varieties of capitalism: The emergence of dependent market economies in East Central Europe, World Politics 2009/61 (4).

Ost David, Illusory corporatism in Eastern Europe: Neoliberal tripartism and postcommunist class identities, Policies \& Society 2000/28 (4).

Petrylaité Daiva, Workers representation in Lithuania: Works councils'role, w: Roger Blanpain, Nikita Lyutov (eds.) Workers' Representation in Central and Eastern Europe: Challenges and Opportunities for Works Councils' System, Wolters Kluwer Law and Business, New York 2014.

Skorupińska Katarzyna, Convergence and Disparities in European Industrial Relations, Comparative Economic Research 2013/16 (3).

Skorupińska Katarzyna, The failure of a new form of employee representation: Polish works councils in comparative perspective, European Journal of Industrial Relations 2018/24 (2). 
Sroka Jacek, Dialog społeczny i stosunki przemysłowe w krajach Europy Środkowo-Wschodniej, w: Andrzej Antoszewski (red.), Systemy polityczne Europy Środkowo-Wschodniej. Perspektywa porównawcza, Wydawnictwo Uniwersytetu Wrocławskiego, Wrocław 2006.

Stanojevič Miroslav, Klarič Matej, The impact of socio-economic shocks on social dialogue in Slovenia, Transfer 2013/19 (2).

Szabo Imre, Between polarization and statism: Effects of the crisis on collective bargaining processes and outcomes in Hungary, Transfer 2013/19 (2).

Viser Jelle, Data Base on Institutional Characteristics of Trade Unions, Wage Setting, State Intervention and Social Pacts, 1960-2014 (ICTWSS), Version 5.0, Amsterdam Institute for Advanced labor Studies, October 2015.

Vitols Sigurt, The European Participation Index (EPI): A Tool for Cross-National Quantitative Comparison, Background paper, ETUI, October 2010.

\title{
Strony internetowe
}

http://ec.europa.eu/eurostat

www.worker-participation.eu

www.ilo.org

http://ec.europa.eu

https://stats.oecd.org/

\section{Katarzyna SKORUPIŃSKA-CIEŚLAK}

\section{INDUSTRIAL RELATIONS IN THE CENTRAL AND EASTERN EUROPE. COMPARED PERSPECTIVE}

\author{
( Summary)
}

The aim of the article is to compare the components of industrial relations in the countries of Central and Eastern Europe (CEE) as well as to determine the level of their convergence in relation to the EU average. The analysis was conducted based on statistic data from the Eurostat, OECD, ILO, AMECO and ICTWSS databases. The strength of "employee voice" in these countries was assessed using the Employee Participation Index (IPP) which include trade union participation, worker representation in the form of works councils and board-level participation. The results of the analyzes show that despite the similarity of industrial relations in the group of CEE countries, the diversity between particular countries is still significant. It turned out that the highest values of IPP have Slovenia and Croatia, while in Bulgaria the strength of the "employee voice" is the lowest.

Keywords: employee participation index; convergence; labor relations 
